\author{
Чернякова Р.А. \\ асистент \\ кафредра менеджменту та логістики \\ Одеська національна академія харчових технологій \\ вул. Канатна, 112, г. Одеса, Україна, 65039 \\ E-mail: renata1982@ukr.net
}

\title{
РОЗВИТОК ІННОВАЦІЙНОЇ ДІЯЛЬНОСТІ НА ПІДПРИЄМСТВАХ ХАРЧОВОЇ ПРОМИСЛОВОСТІ
}

У статті досліджується сучасний стан та основні тенденції інноваційної діяльності підприємств харчової промисловості та її місце в промисловості України, розкриваються основні проблеми інноваційного розвитку. Також виявляються задачі, вирішення яких є необхідною передумовою інноваційного розвитку харчової промисловості. Запропоновано напрями розвитку управління інноваціями на підприємствах та варіанти удосконалення системи управління інноваціями 3 метою підвищення ефективності інноваційної діяльності підприємств харчової промисловості.

Ключові слова: інноваційна діяльність, інновації, виробництво, інноваційний розвиток, управління інноваціями, підприємницька діяльність.

\section{This work is licensed under a Creative Commons Attribution 4.0 International License} http://creativecommons.org/licenses/by/4.0/

Постановка проблеми та її зв'язок з важливими науковими та практичними завданнями. Інноваційна діяльність є невід'ємною складовою виробничо-господарської діяльності підприємства харчової промисловості, зорієнтованої на оновлення і вдосконалення його виробничих сил і організаційноекономічних відносин. Вона спрямована на створення і залучення із зовнішнього середовища таких інновацій, які б сприяли підвищенню конкурентоспроможності підприємства, зміцненню ринкових позицій, забезпечували б перспективу його розвитку. Але інноваційна активність українських підприємств харчової галузі є низькою, що обумовлено такими причинами:

- фрагментарність, непослідовність і незавершеність економічної трансформації;

- орієнтація економіки на інвестування розвитку виробництв, а не на активізацію інноваційної діяльності; структури;

- відсутність розвиненої інноваційної інфра-

- орієнтація на імпорт високотехнологічного устаткування, недостатня увага до розвитку власного науково-технічного потенціалу;

- відсутність кваліфікованого управління інноваційними процесами, спрямованого на підвищення якості харчової продукції, отримання конкурентних переваг;

- недосконалість інструментів правового регулювання інноваційної діяльності [1].

Наслідком цього є неспроможність державних органів управління своєчасно здійснювати необхідні структурні зміни в харчовій промисловості, що поглиблює технологічне відставання України від роз- винених країн. Недостатні темпи інноваційної діяльності підприємств пояснюються нестачею коштів i ресурсів для впровадження нововведень, слабкою зацікавленістю виробників у впровадженні нових розробок, руйнуванням виробничого апарата в харчовій промисловості, що стало причиною зупинки і закриття багатьох підприємств.

Аналіз останніх досліджень і публікацій 3 проблеми. Дослідженню теоретичних і практичних питань організації, управління та розвитку інновацій на підприємствах присвячено значну кількість наукових праць. Серед вітчизняних вчених вагомий внесок здійснили такі відомі українські вчені, як П.П. Борщевський, А.Ф. Гончар, Л.В. Дейнеко, Д.Ф. Крисанов, Ю.П. Лебединський, О.М. Кудирко, М. Якубовський та інші. Аналіз останніх досліджень та публікацій дає змогу прийти до висновку, що поза увагою науковців залишаються невирішеними окремі питання інноваційного оновлення підприємств та заходів щодо його реалізації.

Формулювання цілей дослідження. До складу цілей дослідження відносимо: аналіз сучасного стану, характерних тенденцій та джерел фінансування інноваційної діяльності підприємств харчової промисловості, виявлення проблем, що істотно гальмують розвиток галузі, та визначення шляхів їх розв'язання.

Виклад основних результатів та їх обгрунтування. Серед промислових підприємств України найчастіше інноваційні технології застосовуються на підприємствах по виробництву коксу і продуктів переробки нафти, машинобудування, в хімічній і нафтохімічній промисловості. Що стосується роботи сучасних підприємств харчової промисловості, то про- 
являються труднощі своєчасного просування інноваційних можливостей, централізації ресурсів, оперативного управління інноваційним процесом при мінімальному ризику і невірному виборі інноваційного напряму. Висока продуктивність і ефективність підприємств харчової промисловості як одній із складових економіки України, є пріоритетом в забезпеченні економічної стійкості держави. У зв'язку з процесами економічної інтеграції, потрібний інноваційний розвиток харчової промисловості. Проте, економічна ситуація, що склалася в Україні знаходиться на низькому рівні застосування наукових знань, а примноження інноваційного виробництва відбувається дуже повільно. Залежність країни від імпортних продуктів харчування, надмірні масштаби яких обумовлюють відтік з країни великих коштів для інвестування країн імпортерів своєї продукції в Україну, роблять неможливим створення нових робочих місць, необхідних для забезпечення повної зайнятості робочої сили та сприяння інноваційному розвитку економіки країни. Однак формування України як держави з розвиненими високими технологіями неможливо без впровадження нових технологій, які зможуть витримати жорстку конкуренцію [2].

Практикою усіх країн, що сформували інноваційну економіку, підтверджується, що основним суб'єктом, здатним забезпечити сприятливі умови для інноваційного розвитку, зниження інноваційного ризику, стимулювання і фінансування інновацій, являється держава. Однією $з$ причин повільного інноваційного розвитку в Україні $є$ недостатня державна підтримка сфери дослідження і розробок. При цьому в країні доки ще є один з головних ресурсів - це знання і інтелект. На жаль, через відсутність попиту усередині країни, ресурси ці практично не використовуються. Всі знання і зусилля концентруються на обслуговуванні потреб іноземних компаній, які приходять на український ринок не за готовими технологічними продуктами вітчизняного виробництва, а за науковими, технічними здібностями і інженерними знаннями наших фахівців.

Формально в усіх громадських інститутах України відзначається домінуюча роль науки, нових технологій в підвищенні рівня економічного розвитку країни. Проте, нині в Україні державної інноваційної політики немає в принципі. Ухвалення одних лише законів для її розвитку мало. Потрібне фінансування інноваційних процесів, створення сприятливих умов для розвитку інновацій на підприємствах з боку держави. Проте, на жаль, більшість інвестицій в інноваційні проекти в Україні, і харчова промисловість не виключення, здійснюються за власні кошти суб'єктів підприємницької діяльності. Резерви, які притягуються на фондовому ринку, і довгострокові позики комерційних банків $є$ несуттєвими, а витрати державного i місцевого бюджетів, у тому числі і державні цільові фонди, недостатніми [6].

Аналіз інноваційної діяльності підприємств харчової промисловості дає підстави стверджувати, що інноваційний розвиток підприємств ще не набув позитивної динаміки.

Дослідження показали, що в останні роки спостерігається тенденція зменшення кількості підприємств, які займалися інноваційною діяльністю (з 23\% підприємств у 2001 р. до 16,5\% у 2013 р.) [7]. Встановлено, що за останні роки обсяг реалізованої інноваційної продукції підприємствами харчової промисловості не мав стабільної динаміки, хоча ситуація змінюється й обсяг поступово починає збільшуватися. Досліджено, що на 77 \% підприємств харчової промисловості, які протягом останніх 2006- 2013 років здійснювали інноваційну діяльність, позитивно вплинула на розширення асортименту продукції, на $50-60 \%$ - на збереження і розширення існуючих i створення нових ринків збуту в Україні. Половина ж з обстежених підприємств вважає, що при здійсненні інноваційної діяльності було забезпечено їі відповідність сучасним правилам і стандартам. Кожне друге інноваційне активне підприємство вказало на підвищення гнучкості виробництва, зростання виробничих потужностей, поліпшення умов праці, зниження забрудненості навколишнього середовища, створення нових ринків збуту за межами України, кожне третє скорочення енергетичних витрат, кожне четверте скорочення матеріальних витрат і заміну застарілої продукції [4].

Дуже мала частка підприємств, які проводять активну інноваційну діяльність, та незначні обсяги реалізації інноваційної продукції створюють непривабливий для інвесторів інвестиційний клімат в цій галузі.

В табл.1 розглянуті джерела інноваційної діяльності підприємств харчової промисловості протягом 2005-2013 pp.

Таблиця 1

Джерела фінансування інноваційної діяльності підприємств харчової промисловості (тис. грн.) [8]

\begin{tabular}{|c|c|c|c|c|c|}
\hline \multirow[b]{2}{*}{ Роки } & \multirow{2}{*}{$\begin{array}{c}\text { Загальна } \\
\text { сума витрат }\end{array}$} & \multicolumn{4}{|c|}{ У т.ч. за рахунок коштів } \\
\hline & & власних & $\begin{array}{c}\text { державного } \\
\text { бюджету }\end{array}$ & $\begin{array}{l}\text { іноземних } \\
\text { інвесторів }\end{array}$ & $\begin{array}{c}\text { інші } \\
\text { джерела }\end{array}$ \\
\hline 2005 & 16688,6 & 11614,2 & - & - & 5074,4 \\
\hline 2006 & 46797,1 & 43692,7 & - & 349,0 & 2755,4 \\
\hline 2007 & 28962,0 & 21152,5 & 400,0 & - & 7409,5 \\
\hline 2008 & 61366,3 & 47867,3 & - & - & 13499,0 \\
\hline 2009 & 48563,7 & 28585,6 & 4115,0 & - & 15863,1 \\
\hline 2010 & 44674,3 & 43777,0 & 145,0 & - & 752,3 \\
\hline 2011 & 28417,3 & 19961,6 & 2080,7 & - & 6375,0 \\
\hline 2012 & 75868,8 & 39979,3 & - & - & 35889,5 \\
\hline 2013 & 72451,0 & 27526,0 & 16581,8 & - & 28343,2 \\
\hline
\end{tabular}


Аналізуючи дані табл. 1 можна стверджувати, що підприємства харчової промисловості, що розглядаються, протягом 2005-2013 рр. здійснювали фінансування інновацій, в основному, за рахунок власних коштів. Аналіз стану внутрішніх джерел фінансування інноваційної діяльності підприємств харчової промисловості показав, що, незважаючи на наявність в них резервів, цих джерел недостатньо для масштабної технічної та технологічної модернізації підприємств, навіть за умов їх майбутнього зростання.

Враховуючи сучасний стан інноваційної діяльності та результати проведеного аналізу та оцінки інноваційного потенціалу підприємств харчової промисловості, запропоновано напрями розвитку управління інноваціями на підприємствах, а саме:

- організацію та кадрове забезпечення інноваційної діяльності (введення відділу інновацій, підбір спеціалістів, розробка посадових інструкцій і побудова моделей робочих місць);

- формування інформаційної бази інноваційної діяльності (створення внутрішньої нормативної бази інноваційної діяльності, видання наказів та розробка положень й інструкцій 3 питань інноваційної діяльності, реєстрація та створення бази даних ідей підприємства);

- формування та реалізація інноваційних проектів (розробка бізнес-планів підприємства щодо інноваційних проектів, планування заходів просування на ринок інноваційної продукції).

3 метою підвищення ефективності інноваційної діяльності на різних за масштабом здійснення інноваційної діяльності підприємств харчової промисловості запропоновано різні варіанти удосконалення системи управління інноваціями:

- для великомасштабних інноваційних підприємств шляхом формування спеціалізованого інноваційного відділу - Департаменту інноваційного розвитку;

- для підприємств, в яких, інноваційна діяльність ведеться постійно, але не має цілеспрямованого характеру та відділу, який займається і несе відповідальність за здійснення інноваційної діяльності ввести відділ, який безпосередньо буде займатися інноваційною діяльністю і буде підпорядковуватися вищому керівництву підприємства;

- для підприємств, що мають незначні масштаби та недостатні можливості для здійснення систе- матичної інноваційної діяльності - введення штатної посади менеджера з інноваційної діяльності.

В якості функціональних обов'язків суб'єктів управління інноваційною діяльністю підприємства пропонується закріпити: реєстрацію ідей і розробок в єдиній базі даних (формування інформаційної бази інноваційної діяльності), формування внутрішньої нормативної бази інноваційної діяльності, розробку бюджету і інноваційної програми розвитку підприємства, реалізацію та контроль за виконанням інноваційної програми.

Висновки та перспективи подальших досліджень. Загалом інноваційна діяльність у харчовій промисловості України позначається нестабільністю, недостатньою збалансованістю фінансових джерел, відсутністю чітко визначених пріоритетів та вимагає впровадження державно-приватно партнерських заходів.

Дослідження показали, що в останні роки спостерігається тенденція зменшення кількості підприємств харчової промисловості, які займалися інноваційною діяльністю. По результатам дослідження виявлено, що недостатні темпи інноваційної діяльності підприємств пояснюються нестачею коштів і ресурсів для впровадження нововведень, слабкою зацікавленістю виробників у впровадженні нових розробок Запропоновано напрями розвитку управління інноваціями на підприємствах та варіанти удосконалення системи управління інноваціями з метою підвищення ефективності інноваційної діяльності підприємств харчової промисловості.

На підприємствах харчової промисловості інвестиційна активність повинна бути направлена на забезпечення маркетингу з метою випуску продукції, що буде високорентабельною; організацію пошуку шляхів збільшення виробництва і реалізації продукції; впровадження нових технологій, техніки, а також механізмів фінансування інноваційної діяльності. Для розширення експорту продовольчих товарів в країни Західної Європи потрібне залучення інвестицій в технічне і технологічне оновлення українських підприємств для того, щоб їх продукція задовольняла вимогам 12 міжнародних стандартів ISO на технології, гігієну і безпеку їжі, 14 стандартів на іiі перевірку і аналіз, а також стандартів якості на кожен вид продукції, пропонований до експорту.

\section{Литература}

1. Державний комітет статистики України [Електронний ресурс]. - Режим доступу: www.ukrstat.gov.ua.

2. Комеліна О.В. Напрямки вдосконалення фінансового механізму забезпечення інноваційної діяльності в Україні в сучасних умовах / О.В. Комеліна // Інвестиції: практика та досвід. - 2009. - №17. - С.21-28.

3. Крисанов Д.Ф. Інноваційний фактор розвитку харчової промисловості України / Д.Ф. Крисанов // Економіка України. - 2007. - №4. - С. 71 - 81 .

4. Поддєрьогін А. М. Інновації та їх фінансове забезпечення в харчовій промисловості України / А. М. Поддєрьогін, А. В. Корнилюк // Фінанси України. - 2009. - № 11. - С. 94-100.

5. Статистичний збірник «Наукова та інноваційна діяльність в Україні у 2011 році» [Електронний ресурс] // Державна служба статистики України. - Режим доступу : http://www.ukrstat.gov.ua/ 
6. Стратегія інноваційного розвитку України на 2010-2020 роки в умовах глобалізаційних викликів [Електронний ресурс] : матеріали парламентських слухань у ВРУ 17.06.2009 / За заг. ред. проф. В.І. Полохала // К.: Парламентське видання, 2009. - С.628. - Режим доступу : [http://kno.rada.gov.ua]

7. Сучасний стан, проблеми та стратегія розвитку харчової промисловості України до 2011 року / Л.В.Дейнеко, Л.В.Старшинська, А.О. Коваленко [та ін.] // Економіка промисловості України. - К.: РВПС України НАН України, 2003. - С. 127-135.

8. Товста Т. Л. Інноваційна активність діяльності підприємств харчової промисловості [Електронний ресурс] / Т. Л. Товста // Вісник національного університету «Львівська політехніка». - 2009. - № 628. - 327 с. Режим доступу : http://www.nbuv.gov.ua/portal/natural/VNULP/Ekonomika/2009_628/51.pdf.

\author{
Чернякова P.A. \\ ассистент \\ кафедра менеджмента и логистики \\ Одесская национальная академия пищевых технологий \\ ул. Канатная, 112, г. Одесса, Украина, 65039 \\ E-mail: renata1982@ukr.net
}

\title{
РАЗВИТИЕ ИННОВАЦИОННОЙ ДЕЯТЕЛЬНОСТИ НА ПРЕДПРИЯТИЯХ ПИЩЕВОЙ ПРОМЫШЛЕННОСТИ
}

\begin{abstract}
Инновационная деятельность является неотъемлемой составляющей производственнохозяйственной деятельности предприятий пищевой промышленности, ориентированной на обновление и усовершенствование их производственных сил и организационно-экономических отношений. Она направлена на создание и привлечение из внешней среды таких инноваций, которые бы влияли на повышение конкурентоспособности, укрепление рыночных позиций, и обеспечивали бы перспективу развития предприятия.
\end{abstract}

В данной статье рассматривается нынешнее состояние и основные тенденции инновационной деятельности предприятий пищевой промышленности и их место в промышленности Украины, раскрываются основные проблемы инновационного развития.

Автором был проведен анализ инновационной деятельности предприятий пищевой промышленности, показаны источники финансирования инновационной деятельности.

Рассмотренные предприятия пищевой промышленности на протяжении 2005-2013 годов осуществляли финансирование инноваций, в основном, за счет собственных средств. Анализ состояния внутренних источников фринансирования инновационной деятельности в пищевой промышленности показал, что, несмотря на наличие в них резервов, этих источников недостаточно для масштабной технической и технологической модернизации предприятий, даже при условии их будущего увеличения.

Автором предложены направления развития управления инновациями на предприятиях и варианты усовершенствования системы управления инновациями с целью повышения эффективности инновационной деятельности предприятий пищевой промышленности.

Ключевые слова: инновационная деятельность, инновации, производство, инновационное развитие, управление инновациями, предпринимательская деятельность, пищевая промышленность.

\section{Cherniakova R.}

Assistant

Department of Management and Logistics

Odessa National Academy of Food Technologies

Kanatna str., 112, Odessa, Ukraine, 65039

E-mail: renata1982@ukr.net

\section{THE DEVELOPMENT OF INNOVATION AT THE ENTERPRISES OF THE FOOD INDUSTRY}

Innovative activity is an integral component of industrial and economic activities of the food industry, oriented the updating and improvement their of the productive forces and the organizational and economic 
relations. It aims at the creation and attraction of external environment of innovation, which would affect the increase of competitiveness, strengthen of market positions, and would ensure the prospects development of the enterprise.In this article the present state and the main tendencies of innovative activity of the enterprises of the food industry and their place in the industry of Ukraine is considered, the main problems of innovative development reveal.

This article discusses the current situation and the main trends of innovation activities of the food industry and their place in the Ukrainian industry, the basic problems of innovative development.

The author was analyzed innovation activities of the food industry, showing the sources of financing of innovative activity.

The considered the food industry during the years 2005-2013 was carried financing of innovation, mainly from own funds. Analysis of the status of internal sources financing of innovative activity in the food industry showed that in spite of the presence in them reserves, these sources are not enough for the scale technical and technological modernization of enterprises, even under condition their future increase in.

The author has offered the directions of development of management of innovations at the enterprises and options of improvement of a control system of innovations for the purpose of increase of efficiency of innovative activity of the enterprises of the food industry.

Keywords: innovative activity, innovations, production, innovative development, management of innovations, business activity, food industry.

\section{References}

1. Derzhavnyi komitet statystyky Ukrainy. (2016, February). Retrieved from www.ukrstat.gov.ua

2. Komelina, O. V. (2009). Napriamky vdoskonalennia finansovoho mekhanizmu zabezpechennia innovatsiinoi diialnosti v Ukraini v suchasnykh umovakh. Investytsii: Praktyka Ta Dosvid, 17, 21-28.

3. Krysanov, D. F. (2007). Innovatsiinyi faktor rozvytku kharchovoi promyslovosti Ukrainy. Ekonomika Ukrainy, 4, 71-81.

4. Poddierohin, A. M., \& Kornyliuk, A. V. (2009). Innovatsii ta yikh finansove zabezpechennia v kharchovii promyslovosti Ukrainy. Finansy Ukrainy, 11, 94-100.

5. Statystychnyi zbirnyk «Naukova ta innovatsiina diialnist v Ukraini u 2011 rotsi». (2011, December). Retrieved from http://www.ukrstat.gov.ua/

6. Polokhala, V. I. (2009, November). Stratehiia innovatsiinoho rozvytku Ukrainy na 2010-2020 roky v umovakh hlobalizatsiinykh vyklykiv. Retrieved from http://kno.rada.gov.ua

7. Deineko, L. V., Starshynska, L. V., \& Kovalenko, A. O. (2003). Suchasnyi stan, problemy ta stratehiia rozvytku kharchovoi promyslovosti Ukrainy do 2011 roku. Ekonomika Promyslovosti Ukrainy, 127-135.

8. Tovsta, T. L. (2009). Innovatsiina aktyvnist diialnosti pidpryiemstv kharchovoi promyslovosti. Visnyk Natsionalnoho Universytetu «Lvivska Politekhnika», 628, 327.

Received 15 February 2016

Approved 28 February 2016

Available in Internet 29.03.2016 